\title{
Classification of Tick Species and Detection of Tick-borne Pathogens in Yanbian, China
}

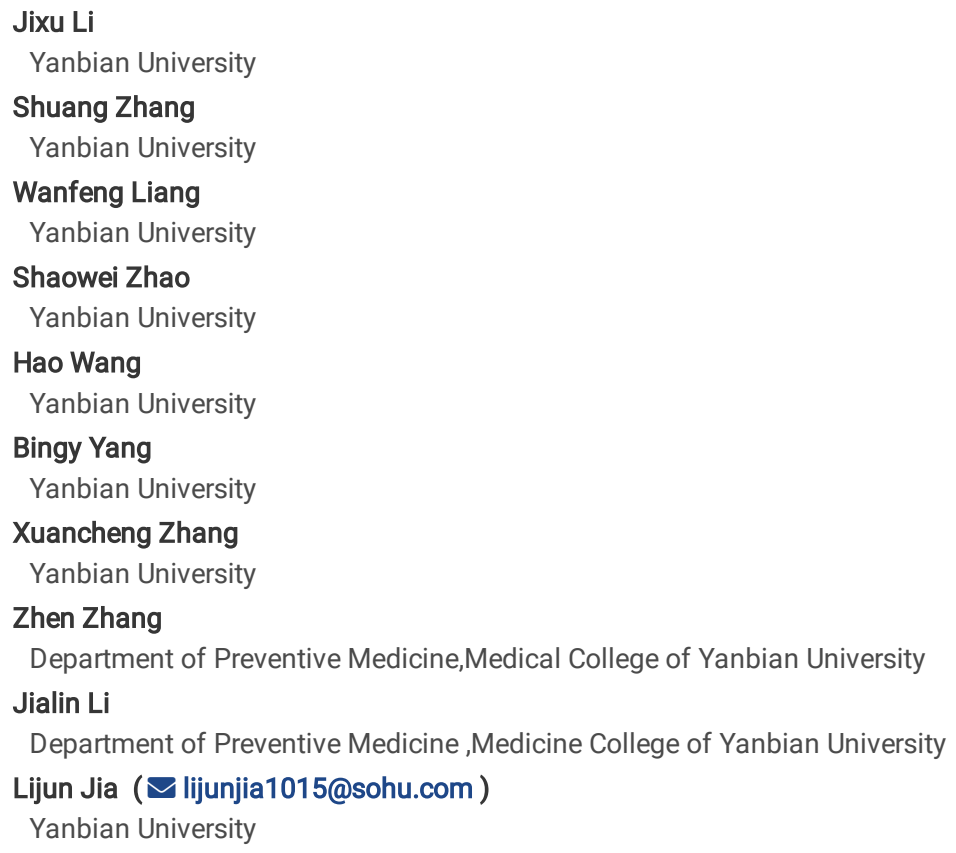




\section{Abstract}

Background

Yanbian is located at the junction between China, Russia, and North Korea. We aimed to determine the species distribution and pathogens carried by ticks in Yanbian.

Methods

A total of 2673 unattached ticks were collected from eight counties and cities in Yanbian and classified morphologically. Candidatus Rickettsia tarasevichiae (CRT), spotted fever group Rickettsia (SFGR), severe fever thrombocytopenia syndrome virus (SFTSV), Theileria, and other pathogens were detected using polymerase chain reaction (PCR) and real-time quantitative polymerase chain reaction followed by phylogenetic and genotypic analyses.

Results

According to the morphological classification, the main tick species in Yanbian were Haemaphysalis longicornis, Ixodes persulcatus, Dermacentor silvarum, Haemaphysalis japonica, and Haemaphysalis concinna. Candidatus Rickettsia tarasevichiae, spotted fever group Rickettsia, severe fever thrombocytopenia syndrome virus, and Theileria orientalis were detected in H. longicornis, Candidatus Rickettsia tarasevichiae, spotted fever group Rickettsia, and severe fever thrombocytopenia syndrome virus were detected in I. persulcatus, H. japonica, and D. silvarum, but only severe fever thrombocytopenia syndrome virus was detected in $H$. concinna. Mixed infection with Candidatus Rickettsia tarasevichiae and severe fever thrombocytopenia syndrome virus was found in $I$. persulcatus and $H$. japonica. The gene sequences of all tested pathogens exhibited $95.7 \%-100 \%$ homology with sequences registered in GenBank.

Phylogenetic analysis showed that different spotted fever group Rickettsia and severe fever thrombocytopenia syndrome virus genotypes were closely related to the Korean strains. We provide the first evidence for the presence of the spotted fever group Rickettsia genotypes of Candidatus Rickettsia longicornii, ompA, ompB, sca4, and rrs, in Haemaphysalis longicornis in Yanbian.

Conclusions

These results provide epidemiological data to support the prevention and control of ticks and tick-borne diseases in the border areas of China, North Korea, and Russia.

\section{Background}

Ticks are arthropod disease vectors widely found in nature, which provide reservoirs for zoonotic diseases [1, 2]. Ticks include the families Ixodidae, Argasidae, and Nuttalliellidae [3,4]. A tick bite penetrates the skin of the host, occasionally resulting in systemic diseases caused by dermatitis, ulcers, or secondary infection. The presence of large numbers of ticks on livestock not only damage the affected area, but also result in anemia and reduce the development, yield, and quality of the livestock, possibly even resulting in death. Increasing studies have clarified the ability of ticks to carry and transmit a variety of diseasecausing pathogens [5], including viruses, protozoa, and bacteria [6]. Ticks and tick-borne diseases do great harm to human health and animal husbandry, and have become an important public health problem worldwide[7, 8].

China covers a vast area and includes regions with dramatically different natural conditions. There are obvious differences in the distributions of ticks between the south and the north of the country, and tick-borne diseases are sometimes reported. Yanbian is located on the border of China with Russia and Korea, in the Changbai Mountains. It is largely covered in forest and has a mid-temperate humid monsoon climate. It is rich in biological resources and provides suitable conditions for tick growth and reproduction. However, the species distribution of ticks and tick-borne pathogens in the border area of China, Russia, and North Korea are not clear. We therefore systematically examined the species distribution and pathogens carried by ticks in Yanbian to provide a scientific basis to support the prevention and control of ticks and tick-borne diseases in Yanbian.

\section{Materials And Methods Sample collection}

A total of 2673 unattached adult ticks were collected from Hunchun, Tumen, Yanji, Dunhua, Helong, Longjing, Wangqing, and Antu in Yanbian, China, on sunny mornings from April to August 2019, using the flag-laying method. The ticks were stored live in water in the refrigerator at $4^{\circ} \mathrm{C}$. The date and place of collection was recorded for each sample. All experimental procedures involving animals were conducted according to the Ethical Principles of Animal Research issued by Yanbian University.

\section{Tick classification}

The collected ticks were classified morphologically based on the 'Classification and Identification of Important Medical Insects of China' [9] and 'Ticks of Japan, Korea, and the Ryukyu Islands' [10].

\section{Tick treatment}

The ticks were grouped according to species and region. Each tick was washed three times in normal saline, placed in a $1.5 \mathrm{~mL}$ centrifuge tube, and $600 \mathrm{~L}$ phosphate-buffered saline was added. The tick was then ground with a tissue breaker (TissueLyserll; Qiagen, GER), followed by centrifugation at $1,300 \times g$ for $1 \mathrm{~min}$, and $200 \mathrm{~L}$ of the supernatant was collected to extract nucleic acid. 


\section{Pathogen gene detection}

Nucleic acids were extracted using a nucleic acid extraction kit (Suzhou Tianlong Science and Technology Co., Ltd., Suzhou, China). The Candidatus Rickettsia tarasevichiae (CRT) ompA gene and 17-kDa genes were detected as described by Jia et al. [11]. The spotted fever group Rickettsia (SFGR) Candidatus Rickettsia longicornii ompA, ompB, sca4, rrs genes were detected as described by Jiang et al. [12], the severe fever thrombocytopenia syndrome virus (SFTSV) Small, Medium, and Large gene segments were detected as described by Liu et al. [13], the Theileria orientalisMPSP gene was detected as described by Ota et al. [14], and the Theileria sinensisMPSP gene was detected as described by Liu et al. [15]. The primers for these genes are listed in Table 1 .

Table 1

Amplification of primer sequences of genes of different pathogens

\begin{tabular}{|c|c|c|c|c|c|}
\hline Pathogen gene & $\begin{array}{l}\text { Primer } \\
\text { name }\end{array}$ & Sequence $\left(5^{\prime}-3^{\prime}\right)$ & $\begin{array}{l}\text { Annealing } \\
\text { temperature }\left({ }^{\circ} \mathrm{C}\right)\end{array}$ & $\begin{array}{l}\text { Fragment } \\
\text { size (bp) }\end{array}$ & reference \\
\hline \multirow[t]{4}{*}{ CRT ompA } & Rr190.70p & ATGGCGAATATTTCTCCAAAA & \multirow[t]{2}{*}{60} & \multirow[t]{4}{*}{346} & \multirow{4}{*}{$\begin{array}{l}\text { Jia et al. } \\
(2013)\end{array}$} \\
\hline & $\operatorname{Rr} 190.602 n$ & AGTGCAGCATTCGC TCCСCCT & & & \\
\hline & $\begin{array}{l}\text { 190.70- } \\
38 s 1\end{array}$ & AAAACCG CTTTATTCACC & \multirow[t]{2}{*}{58} & & \\
\hline & $\begin{array}{l}190.602- \\
384 \mathrm{r} 1\end{array}$ & GGCAAC AAGTTACCTCCT & & & \\
\hline \multirow[t]{4}{*}{ CRT $17 \mathrm{kDa}$} & $17 \mathrm{~K} 3$ & GCTTTACAAAATTCTAAAAACCATATA & \multirow[t]{2}{*}{50} & \multirow[t]{4}{*}{395} & \multirow{4}{*}{$\begin{array}{l}\text { Jia et al. } \\
\text { (2013) }\end{array}$} \\
\hline & $17 K 5$ & TGTCTATCAATTCACAACTTGCC & & & \\
\hline & 17KD113s1 & ATTGTCCGTCAGGTTGGC & \multirow[t]{2}{*}{52} & & \\
\hline & 17KD408r1 & CGGGCGGTATGAATAAGC & & & \\
\hline \multirow{2}{*}{$\begin{array}{l}\text { SFGR } \\
\text { Candidatus Rickettsia } \\
\text { longicornii } \\
\text { ompA }\end{array}$} & H-LompA-F & TTTAATTGATTTAATTTTTATTAAGGTTTACATATGGCG & \multirow[t]{2}{*}{60} & \multirow[t]{2}{*}{647} & \multirow{2}{*}{$\begin{array}{l}\text { Jiang et } \\
\text { al. } \\
(2018)\end{array}$} \\
\hline & H-LompA-R & GTCTTGACAGTTATTATACCTCCTCCAT & & & \\
\hline \multirow{2}{*}{$\begin{array}{l}\text { SFGR } \\
\text { Candidatus Rickettsia } \\
\text { longicornii } \\
\text { ompB }\end{array}$} & $\begin{array}{l}\text { H-LompB- } \\
\text { F1 }\end{array}$ & GTTCAGCTATGGGTGCTGCTATACAG & \multirow[t]{2}{*}{63} & \multirow[t]{2}{*}{1203} & \multirow{2}{*}{$\begin{array}{l}\text { Jiang et } \\
\text { al. } \\
\text { (2018) }\end{array}$} \\
\hline & $\begin{array}{l}\text { H-LompB- } \\
\text { R1 }\end{array}$ & GCACTAGCACTTGCTAAAGTACCGT & & & \\
\hline \multirow{2}{*}{$\begin{array}{l}\text { SFGR } \\
\text { Candidatus Rickettsia } \\
\text { longicornii }\end{array}$} & H-Lsca4-F2 & AGTTCTCAGTCCAGCACAACAAC & \multirow[t]{2}{*}{63} & \multirow[t]{2}{*}{885} & \multirow{2}{*}{$\begin{array}{l}\text { Jiang et } \\
\text { al. } \\
(2018)\end{array}$} \\
\hline & H-Lsca4-R2 & GCCTTTACCAGCTCATCTACTTT & & & \\
\hline \multirow{2}{*}{$\begin{array}{l}\text { SFGR } \\
\text { Candidatus Rickettsia } \\
\text { longicornii }\end{array}$} & H-L16S-F & TGCAAGTCGAACGGACTAATTGG & \multirow[t]{3}{*}{65} & \multirow[t]{3}{*}{976} & \multirow{3}{*}{$\begin{array}{l}\text { Jiang et } \\
\text { al. } \\
\text { (2018) }\end{array}$} \\
\hline & H-L16S-R & AATGAGGGTTGCGCTCGTTG & & & \\
\hline \multicolumn{3}{|l|}{$r r s$} & & & \\
\hline SFTSV & S-F1 & ACACAAAGACCCCCTTCATTTGGA & \multirow[t]{2}{*}{58} & \multirow[t]{2}{*}{588} & \multirow{2}{*}{$\begin{array}{l}\text { Liu et al. } \\
\text { (2016) }\end{array}$} \\
\hline Small & S-R1 & TGGAGGAGGGCCACATCCAG & & & \\
\hline SFTSV & $\mathrm{M}-\mathrm{F} 1$ & GATGAGATGGTCCATGCTGATTCT & \multirow[t]{2}{*}{58} & \multirow[t]{2}{*}{560} & Liu et al. \\
\hline Medium & M-R1 & CTCATGGGGTGGAATGTCCTCAC & & & \\
\hline SFTSV & L-F1 & ACACAGAGACGCCCAGATGAAC & 60 & 684 & Liu et al. \\
\hline Large & L-R1 & GСCTCAAGCTCTTCСTСАСTCTTCTG & & & $(2016)$ \\
\hline T. orientalis & $\mathrm{P} 1$ & CACGCTATGTTGTCCAAGAG & 53 & 875 & Liu et al. \\
\hline MPSP & $\mathrm{P} 2$ & TGTGAGACTCAATGCGCCTA & & & $(2010)$ \\
\hline T. sinensis & P3 & CACTGCTATGTTGTCCAAGAGATATT & 56 & 887 & Liu et al. \\
\hline MPSP & $\mathrm{P} 4$ & AATGCGCCTAAAGATAGTAGAAAAC & & & $(2010)$ \\
\hline
\end{tabular}

\section{Homology and phylogenetic analyses}

The PCR products of positive samples were sent to Shanghai Shenggong Co., Ltd. for sequencing. Correct gene sequences were analyzed via DNAStar and GenBank, and phylogenetic trees were constructed using the neighbor-joining method with a Kimura 2-parameter model using MEGA7 software. 


\section{Statistical analysis}

Data were processed using Excel 2007 and statistical analysis was carried out using SAS8.2 software. Numerical data were expressed as a constituent ratio $(\%)$ and positive rate (\%), where the constituent ratio $(\%)$ = number of each tick species in same location / total number of all tick species in same location $\times$ $100 \%$, and the positive rate $(\%)=$ number of positive samples detected for pathogens $/$ total number of tested samples of the same species $(n) \times 100 \%$.

\section{Results}

\section{Tick species survey results}

A total of 2673 ticks were collected, including 1373 H. longicornis (51.37\%), 651 Ixodes persulcatus (24.35\%), 357 Haemaphysalis japonica (13.36\%), 140 Dermacentor silvarum (5.24\%), and 152 Haemaphysalis concinna (5.68\%). H. longicornis and l. persulcatus were the dominant local tick species (Table 2).

Table 2

composition of tick species in 8 counties and cities of Yanbian

\begin{tabular}{|c|c|c|c|c|c|c|c|c|c|c|c|}
\hline \multirow[t]{2}{*}{ Location } & \multicolumn{2}{|c|}{$\begin{array}{l}\text { Haemaphysalis } \\
\text { longicomis }\end{array}$} & \multicolumn{2}{|c|}{ Ixodes persulcatus } & \multicolumn{2}{|c|}{$\begin{array}{l}\text { Haemaphysalis } \\
\text { japonica }\end{array}$} & \multicolumn{2}{|c|}{ Dermacentor silvarum } & \multicolumn{2}{|c|}{$\begin{array}{l}\text { Haemaphysalis } \\
\text { concinna }\end{array}$} & \multirow{2}{*}{$\begin{array}{l}\text { Total } \\
\begin{array}{l}\text { Quantity } \\
\text { (only) }\end{array}\end{array}$} \\
\hline & $\begin{array}{l}\text { Quantity } \\
\text { (only) }\end{array}$ & $\begin{array}{l}\text { Constituent } \\
\text { ratio (\%) }\end{array}$ & $\begin{array}{l}\text { Quantity } \\
\text { (only) }\end{array}$ & $\begin{array}{l}\text { Constituent } \\
\text { ratio (\%) }\end{array}$ & $\begin{array}{l}\text { Quantity } \\
\text { (only) }\end{array}$ & $\begin{array}{l}\text { Constituent } \\
\text { ratio (\%) }\end{array}$ & $\begin{array}{l}\text { Quantity } \\
\text { (only) }\end{array}$ & $\begin{array}{l}\text { Constituent } \\
\text { ratio (\%) }\end{array}$ & $\begin{array}{l}\text { Quantity } \\
\text { (only) }\end{array}$ & $\begin{array}{l}\text { Constituent } \\
\text { ratio (\%) }\end{array}$ & \\
\hline $\begin{array}{l}\text { Hun } \\
\text { chun }\end{array}$ & 348 & 68.24 & 129 & 25.29 & 17 & 3.33 & 16 & 3.14 & 0 & 0.00 & 510 \\
\hline Tu men & 37 & 20.22 & 0 & 0.00 & 120 & 65.57 & 14 & 7.65 & 12 & 6.56 & 183 \\
\hline Yan ji & 192 & 48.98 & 174 & 44.39 & 0 & 0.00 & 0 & 0.00 & 26 & 6.63 & 392 \\
\hline Dun hua & 0 & 0.00 & 106 & 42.74 & 125 & 50.40 & 17 & 6.85 & 0 & 0.00 & 248 \\
\hline He long & 87 & 26.69 & 158 & 48.46 & 67 & 1.84 & 14 & 4.29 & 0 & 0.00 & 326 \\
\hline $\begin{array}{l}\text { Long } \\
\text { jing }\end{array}$ & 426 & 88.38 & 56 & 11.62 & 0 & 0.00 & 0 & 0.00 & 0 & 0.00 & 482 \\
\hline $\begin{array}{l}\text { Wang } \\
\text { qing }\end{array}$ & 283 & 84.73 & 23 & 6.89 & 28 & 8.38 & 0 & 0.00 & 0 & 0.00 & 334 \\
\hline An tu & 0 & 0.00 & 5 & 2.53 & 0 & 0.00 & 79 & 39.90 & 114 & 57.58 & 198 \\
\hline Total & 1373 & 51.37 & 651 & 24.35 & 357 & 13.36 & 140 & 5.24 & 152 & 5.68 & 2673 \\
\hline
\end{tabular}

Pathogen gene detection

By detecting different tick-pathogen genes, we detected CRT, SFGR, SFTSV, and T. orientalis in $H$. longicornis, CRT, SFGR, and SFTSV in I. persulcatus and $H$. japonica, CRT and SFTSV in D. silvarum, and only SFTSV in $H$. concinna. Moreover, different CRT and SFGR genotypes were detected in $H$. longicornis and $H$. japonica, and different SFTSV genotypes in H. concinna. There was mixed infection with CRT and SFTSV in I. persulcatus, H. japonica, and $D$. silvarum. The highest incidences of CRT/SFTSV co-infection included 13 cases $(2.00 \%)$ in I. persulcatus, five cases (1.40\%) in H. japonica, and one case (0.71\%) in D. silvarum. T. orientaliswas detected in H. longicornis. T. sinensis was not detected in any ticks (Table 3). 
Table 3

Infection of pathogens in different tick species in Yanbian, China

\begin{tabular}{|c|c|c|c|c|c|c|c|c|c|c|}
\hline Species & $\begin{array}{l}\text { CRT } \\
\text { ompA }\end{array}$ & $\begin{array}{l}\text { CRT } \\
17 \mathrm{kDa}\end{array}$ & $\begin{array}{l}\text { SFGR } \\
\text { Candidatus } \\
\text { Rickettsia } \\
\text { longicornii } \\
\text { ompA }\end{array}$ & $\begin{array}{l}\text { SFGR } \\
\text { Candidatus } \\
\text { Rickettsia } \\
\text { longicornii } \\
\text { ompB }\end{array}$ & $\begin{array}{l}\text { SFGR } \\
\text { Candidatus } \\
\text { Rickettsia } \\
\text { longicomii } \\
\text { sca4 }\end{array}$ & $\begin{array}{l}\text { SFGR } \\
\text { Candidatus } \\
\text { Rickettsia } \\
\text { longicornii } \\
\text { rs }\end{array}$ & $\begin{array}{l}\text { SFTSV } \\
\text { Small }\end{array}$ & $\begin{array}{l}\text { SFTSV } \\
\text { Medium }\end{array}$ & $\begin{array}{l}\text { SFTSV } \\
\text { Large }\end{array}$ & $\begin{array}{l}\text { CRT + } \\
\text { SFTSV }\end{array}$ \\
\hline & $\begin{array}{l}\text { Positive } \\
\text { number } \\
\text { (positive } \\
\text { rate \%) }\end{array}$ & $\begin{array}{l}\text { Positive } \\
\text { number } \\
\text { (positive } \\
\text { rate \%) }\end{array}$ & $\begin{array}{l}\text { Positive } \\
\text { number } \\
\text { (positive } \\
\text { rate \%) }\end{array}$ & $\begin{array}{l}\text { Positive } \\
\text { number } \\
\text { (positive } \\
\text { rate \%) }\end{array}$ & $\begin{array}{l}\text { Positive } \\
\text { number } \\
\text { (positive } \\
\text { rate \%) }\end{array}$ & $\begin{array}{l}\text { Positive } \\
\text { number } \\
\text { (positive } \\
\text { rate \%) }\end{array}$ & $\begin{array}{l}\text { Positive } \\
\text { number } \\
\text { (positive } \\
\text { rate \%) }\end{array}$ & $\begin{array}{l}\text { Positive } \\
\text { number } \\
\text { (positive } \\
\text { rate \%) }\end{array}$ & $\begin{array}{l}\text { Positive } \\
\text { number } \\
\text { (positive } \\
\text { rate \%) }\end{array}$ & $\begin{array}{l}\text { Positive } \\
\text { number } \\
\text { (positive } \\
\text { rate \%) }\end{array}$ \\
\hline $\begin{array}{l}\text { Haemaphysalis } \\
\text { longicornis } \\
(n=1373)\end{array}$ & $22(1.60)$ & $23(1.68)$ & $323(23.53)$ & 261(19.01) & $287(20.90)$ & $364(26.51)$ & 16(1.17) & 13(0.95) & 15(1.09) & 0 \\
\hline $\begin{array}{l}\text { Ixodes } \\
\text { persulcatus } \\
(n=651)\end{array}$ & $71(10.91)$ & $57(8.76)$ & $7(1.08)$ & $5(0.77)$ & $5(0.77)$ & $6(0.92)$ & $22(3.38)$ & $17(2.61)$ & 26(3.99) & $13(2.00)$ \\
\hline $\begin{array}{l}\text { Haemaphysalis } \\
\text { japonica( } \mathrm{n}= \\
357)\end{array}$ & $26(7.28)$ & $25(7.00)$ & $8(2.24)$ & $6(1.68)$ & $7(1.96)$ & $7(1.96)$ & $38(10.64)$ & $23(6.44)$ & $27(7.56)$ & $5(1.40)$ \\
\hline $\begin{array}{l}\text { Dermacentor } \\
\text { silvarum }(n= \\
140)\end{array}$ & $28(20.00)$ & $49(35.00)$ & 0 & 0 & 0 & 0 & $44(31.43)$ & $26(18.57)$ & $37(26.43)$ & $1(0.71)$ \\
\hline $\begin{array}{l}\text { Haemaphysalis } \\
\text { concinna( } \mathrm{n}= \\
152)\end{array}$ & 0 & 0 & 0 & 0 & 0 & 0 & $17(11.18)$ & $11(7.24)$ & $19(12.50)$ & 0 \\
\hline $\begin{array}{l}\text { Total } \\
(n=2673)\end{array}$ & $147(5.50)$ & $154(5.76)$ & $338(12.64)$ & $272(10.18)$ & 299(11.19) & $377(14.10)$ & $137(5.13)$ & $90(3.37)$ & $124(4.64)$ & $19(0.71)$ \\
\hline
\end{tabular}

\section{Sequence and phylogenetic analyses of pathogen genes}

Analysis of the sequence homology between the CRT gene sequence obtained from I. persulcatus and the GenBank sequence showed that the CRT ompA gene sequence of the ticks in Yanbian shared 100\% homology with the Henan Xinyang strain (KX365196.1), Northeast China strain (KT899079.1), Heilongjiang Mudanjiang strain (JX996053). The nucleotide sequence homologies of the 17-kDa gene between Henan Xinyang (KX365195.1) and the Heilongjiang Mudanjiang (KT259906) and Jilin (KT384433) strains were 99.7\% and 100\%, respectively. Phylogenetic analysis showed that the CRT ompA gene of Yanbian strain YB02 (MT511087) clustered with the Henan Xinyang (KX365196.1) and Heilongjiang strains (JX996053). The 17-kDa gene (MT511086) clustered with the Japanese (LC379446.1) and Heilongjiang (JX996052.1) strains (Fig. 1).

From the samples positive for SFGR Candidatus Rickettsia longicornii, four gene sequences of ompA, ompB, sca4,and rrs were obtained by PCR amplification. Sequence homology analysis showed that the four gene sequences (MT511088, MT511089, MT511090, and MT535574) had 100\%, 99.70\%, 100\%, and 95.70\% homology, respectively, with the corresponding fragments (MG906676, MG906675, MG906677, and MG906672) of SFGR Candidatus Rickettsia longicornii newly discovered in the Korean H. longicornis sample (ROK-HL727). Phylogenetic analysis showed that the sequence of Candidatus Rickettsia longicornii ompA (MT511088) was located on the same branch as the Korean ROK-HL727 strain (MG906676.1), Chinese Changchun Candidatus Rickettsia jingxinensisHI6 strain (KT899081.1), and Chinese Dandong 19070 strain (MH427382.1). The ompB (MT511089) gene sequence was in the same clade as the Chinese HC strain (MK620854.1), and exhibited a close evolutionary relationship with the Korean Candidatus Rickettsia longicorniiROK-HL727 strain (MG906675.1). The rrs (MT535574) gene sequence was located in the same branch as the Candidatus Rickettsia jingxinensis-related sequence (MH500204) found in H. longicornis in China and the Candidatus Rickettsia longicorniiROK-HL727 strain (MG906672.1) in Korea. The sca4 (MT511090) gene sequence was also closely related to the Korean Candidatus Rickettsia longicornii ROK-HL727 strain (MG906677.1) (Fig. 2).

The SFTSV Large (MT517309), Medium (MT517308), and Small (MT517307) gene sequences showed 98\%- 99\% homology with the SFTSV gene sequences identified in China and South Korea according to homology analysis. Phylogenetic analysis showed that the SFTSV Small gene sequence from ticks in Yanbian was in the same clade as the SFTSV gene sequence (KT890282.1) of Jilin ticks in China. The Medium gene sequence was located in the same branch as the Chinese JS2014-18 strain (KR230781.1), and the Small sequence was located in the same branch as the Chinese JS2014-18 strain (KR230761.1) and was closely related to SFTSV isolated from Zhejiang and South Korea (Fig. 3).

There was $99.4 \%$ homology between the T. orientalis MPSP gene (MT517304) and the published GenBank entry number (MG664537.1). Phylogenetic analysis showed that the sequence of the T. orientalis MPSP (MT517304) gene in the ticks was located in the same branch as MPSP (MG664537.1) in the Chinese Chongqing strain (Fig. 4).

\section{Discussion}

Yanbian is located at the junction of China, North Korea, and Russia, and has a long border. Strengthening ecological and environmental protection in China means that the species distribution along the border has gradually diversified; the numbers and species of ticks are thus constantly changing, and their 
activity is increasing. Ticks and other vectors in the border zone can migrate to each other using various methods, increasing the risk of tick-borne diseases. In this study, 2673 ticks collected from eight counties and cities in Yanbian were classified and analyzed. H. longicornis and I. persulcatus were the dominant tick species in Yanbian. H. longicornis has strong reproductive ability and environmental adaptability, and is widely distributed throughout Asia and the Pacific, including China, Russia, South Korea, Japan, Australia, New Zealand, and the South Pacific islands. It is often parasitic in medium and large wild and domestic animals, whereas humans are accidental hosts. $H$. longicornis spreads a variety of pathogens that can affect wild animals and livestock, as well as human health.

Ticks can be infected with viruses, bacteria, including Rickettsia and spirochetes, and other pathogens. In addition, ticks can act as both vectors and hosts in the process of infectious disease transmission. The main research into tick-borne pathogen co-infections is currently focused on Borrelia burgdofferi, Babesia microti, Ehrlichia, and Anaplasma phagocytophilum [16]. Previous studies confirmed that one-third of patients with a CRT infection had neurological symptoms that differed from other SFGR infections [17], and were associated with a higher case-fatality rate when co-infected with SFTSV [18]. More attention should thus be paid to SFTSV transmission through both tick bites and close contact with infected cases [19]. In this study, we confirmed the existence of CRT/SFTSV co-infection in I. persulcatus $(\mathrm{n}=13), H$. japonica $(\mathrm{n}=5)$, and D. silvarum $(\mathrm{n}=1)$ in Yanbian. I. persulcatus is a common dominant tick species in Yanbian, and is especially widely distributed in Hunchun, Yanji, Helong, and other regions, resulting in a high risk of CRT and SFTSV infection via tick bites in these regions.

SFGR forms a long-lasting infection cycle between ticks and mammals and can also be transmittedvertically through tick eggs, making ticks the main host and vector of SFGR. Liu et al. [20] identified the new SFGR genotype Candidatus Rickettsia jingxinensis in H. longicornis in Northeast China, and Jiang et al. [12] reported the new SFGR genotype Candidatus Rickettsia longicornii in H. longicornis in Korea. The new SFGR genotypes Candidatus Rickettsia longicornii ompA, ompB, sca4, and rrs were detected in H. Iongicornis, I. persulcatus, and H. japonica in Yanbian. The SFGR Candidatus Rickettsia longicornii gene sequence detected in ticks displayed high homology with the newly discovered Candidatus Rickettsia longicornii genotype (ROK-HL727)-related gene sequence in South Korea, and also had a high homology with the ompA gene and ompB gene of an unknown SFGR genotype found in H. longicornis from Dandong, China (border between China and North Korea). This suggests that the new SFGR Candidatus Rickettsia longicornii genotypes are widely distributed in the border region between China and North Korea. Although there have been no reports of infections caused by the new SFGR genotype, the ompA gene sequence of Candidatus Rickettsia longicornii found in Yanbian was highly homologous to an unknown species of Rickettsia detected in mouse spleen tissue in South Korea. These findings indicate that the Candidatus Rickettsia longicornii identified in this study was likely to be infectious in mammalian hosts and even in humans. It is therefore necessary to strengthen the surveillance for the SFGR Candidatus Rickettsia longicornii genotypes in ticks and their hosts in the border regions of China, North Korea, and Russia, as well as in other areas with a concentrated distribution of $H$. longicornis, to prevent cross-border transmission and an epidemic of tick-borne diseases affecting human health and animal husbandry.

SFTS is a novel infectious disease that was first discovered in China. Its main clinical manifestations consist of acute fever, thrombocytopenia, and leukopenia. The pathogen was isolated from a patient's serum and termed SFTSV [21]. At present, most ticks detected and isolated from cases of SFTS were $H$. longicornis. The first report of the disease occurred when SFTSV was detected in H. longicornis on the skin of sheep in Henan Province, China [22], and SFTSV was isolated from H. longicornis on sheep in the SFTS epidemic area in Shandong Province, China [23]. SFTSV was first isolated from $H$. longicornis in Korea [24]. In the current study, the SFTSV Small, Medium, and Large gene sequences were obtained by gene amplification, and homology analysis indicated 98\%-99\% homology with the SFTSV gene sequence found in South KoreaPhylogenetic analysis showed that the SFTSV Small, Medium, and Large gene sequences were in the same clade as isolates from Jilin and Jiangsu, respectively, and were closely related to SFTSV isolated from Zhejiang and South Korea This may be related to the parasitism of migratory birds by ticks in the east or SFTSV transmission by migratory birds themselves during cross-sea migration. Korean researchers suggested that migratory birds may play an important role in the spread of SFTSV [25]. The above results suggest that the border area of China, North Korea, and Russia is a key region for preventing tick-borne SFTSV, and should thus be considered in the prevention and control of imported infectious diseases in the border region.

T. orientalis is a protozoon that infects cattle and buffalo, and which is generally transmitted by ticks of the genus Haemaphysalis [26]. T. sinensis was originally isolated from naturally infected cattle by Bai Qi and others in Gansu Province of China. Chinese researchers investigated the taxonomic status of this undetermined species by comparing it with other bovine Theileria worms via morphological comparison, and inoculation transmission and host specificity tests. It was finally termed T. sinensis [27]. T. orientalis is transmitted by H. longicornis, H. concinna, and H. japonica. However, the vector tick species differ between regions; for example, $H$. japonica is the main vector of Oriental Taylor disease in Russia, followed by $H$. concinna, while $H$. concinna is also the main vector in Korea, whereas $H$. longicornis is the main vector in China and Japan. In this investigation, we detected T. orientalis in $H$. longicornis but failed to detect $T$. sinensis in any ticks. This may be related to the collection area and small numbers of its vector, $H$. japonica.

\section{Conclusions}

H. longicornis and I. persulcatus are the dominant tick species in Yanbian, China. Four pathogens (CRT, SFGR, SFTSV and T. orientalis) were detected in the tick species collected in this study, and CRT/SFTSV co-infection was also identified in I. persulcatus and $H$. japonica. Moreover, this study provides the first evidence of the SFGR genotypes Candidatus Rickettsia longicorniiompA, ompB, sca4, and rrs in H. longicornis in Yanbian, China. Moreover, T. orientalis was detected in $\mathrm{H}$. longicornis. These findings provide epidemiological data to support the prevention and control of ticks and tick-borne diseases in the border region of China, North Korea, and Russia.

\section{Abbreviations}

CRT: Candidatus Rickettsia tarasevichiae, SFGR: spotted fever group Rickettsia; SFTSV: severe fever thrombocytopenia syndrome virus; PCR: polymerase chain reaction. 


\section{Declarations}

\section{Acknowledgements}

Not applicable.

\section{Declarations}

Not applicable.

\section{Ethics approval and consent to participate}

Not applicable.

\section{Consent for publication}

Not applicable.

\section{Availability of data and material}

All data supporting the conclusions of this article are included within the article.

\section{Competing interests}

The authors declare that they have no competing interests.

\section{Funding}

The project was supported by the National Natural Science Foundation of China (31760729 and 31360605), the Scientific Research and Innovation Team Project of Yanbian University, the Talent Fund Funded Talent Project of Jilin Province (project no. [2019] 874), the Leading Talents and Teams of Young and Middle-aged Technological Innovation in Jilin Province (20200301034RQ) and supported by the 111 Project (D20034).

\section{Authors contributions}

JXL: Methodology, Validation, Statistical analysis the results,Writing-Original Draft.

SZ: Validation, Statistical analysis the results.

WFL: Investigation, Recorded samples'data.

SWZ: Edited and revised the manuscript.

HW: Investigation, Recorded samples'data.

BYY: Investigation, Recorded samples'data.

XCZ: Investigation, Recorded samples'data.

ZZ: Investigation, Recorded samples'data.

JLL: Investigation, Recorded samples'data.

LJJ: Conceptualization, Writing-Review \& Editing, Funding acquisition.

\section{References}

1. Parola P, Paddock CD, Raoult D. Tick-borne rickettsioses around the world: emerging diseases challenging old concepts. Clin Microbiol Rev. 2005;18 4:71956; doi: 10.1128/cmr.18.4.719-756.2005.

2. Ze C, Tinghuan W. The world list of ticks. 2. Ixodinae (Acari:Ixodida:Ixodidae). Chin J Parasitol Parasitic Dis.2017;35 04:371-81.

3. Xiaojun Y, Ze C, Jingze L. The Valid Genus and Species Names of Ticks (Acari:Ixodida:Argasidae, Ixodidae) in China. J Hebei Norm U (Nat Sci).2008; 04:529-33.

4. Horak IG, Camicas JL, Keirans JE. The Argasidae, Ixodidae and Nuttalliellidae (Acari: Ixodida): a world list of valid tick names. Exp Appl Acarol.2002;28 14:27-54; doi: 10.1023/a:1025381712339.

5. Schötta AM, Wijnveld M, Stockinger H, Stanek G. Approaches for Reverse Line Blot-Based Detection of Microbial Pathogens in Ixodes ricinus Ticks Collected in Austria and Impact of the Chosen Method. Appl Environ Microbiol.2017;83 13; doi: 10.1128/aem.00489-17.

6. Yu Z, Wang H, Wang T, Sun W, Yang X, Liu J. Tick-borne pathogens and the vector potential of ticks in China. Parasite Vector.2015;8:24; doi: 10.1186/s13071-014-0628-x.

7. Wei L. Emerging tick borne agents in China. Infect Dis Inform.2017;30 01:11-4; doi: 10.3969/j.issn.1007-8134.2017.01.005. 
8. Oliver JH. Biology and Systematics of Ticks (Acari:Ixodida). Annu Rev Ecol Syst.1989;20.

9. Lu BL,Wu HY. Classification and Identification of Important Medical Insects of China [M].Henan Science and Technology Publishing House,China.2003: $652-713$.

10. Yamaguti N,Tipton VJ,Keegan HL, et al.Ticks of Japan, Korea, and the Ryukyu islands Brigham Young University Science Bulletin, Biological Series [Z]. $1971.15,1-226$.

11. Jia N, Jiang JF, Huo QB, Jiang BG, Cao WC. Rickettsia sibirica subspecies sibirica BJ-90 as a cause of human disease. N Engl J Med.2013;369 12:1176-8; doi: $10.1056 /$ NEJMc1303625.

12. Jiang J, An H, Lee JS, O'Guinn ML, Kim HC, Chong ST, et al. Molecular characterization of Haemaphysalis longicornis-borne rickettsiae, Republic of Korea and China. Ticks Tick-borne Dis.2018;9 6:1606-13; doi: 10.1016/j.ttbdis.2018.07.013.

13. Liu H, Li Z, Wang Z, He B, Wang S, Wei F, et al. The first molecular evidence of severe fever with thrombocytopenia syndrome virus in ticks in Jilin, Northeastern China. Ticks Tick-borne Dis.2016;7 6:1280-3; doi: 10.1016/j.ttbdis.2016.06.007.

14. Ota N, Mizuno D, Kuboki N, Igarashi I, Nakamura Y, Yamashina $\mathrm{H}$, et al. Epidemiological survey of Theileria orientalis infection in grazing cattle in the eastern part of Hokkaido, Japan. J Vet Med Sci.2009;71 7:937-44; doi: 10.1292/jvms.71.937.

15. Liu A, Guan G, Liu Z, Liu J, Leblanc N, Li Y, et al. Detecting and differentiating Theileria sergenti and Theileria sinensis in cattle and yaks by PCR based on major piroplasm surface protein (MPSP). Exp Parasitol. 2010;126 4:476-81; doi: 10.1016/j.exppara.2010.05.024.

16. FK B. Advance in the research of coinfection of tick-borne diseases. Chin Trop Med.2007;01:112-4.

17. Liu W, Li H, Lu QB, Cui N, Yang ZD, Hu JG, et al. Candidatus Rickettsia tarasevichiae Infection in Eastern Central China: A Case Series. Ann Intern Med.2016;164 10:641-8; doi: 10.7326/m15-2572.

18. Yadi F, Jiangong H, Xiaoming. C, Chentao. G, Ying W, Xiaoai Z, et al. Co-infection of spotted fever group rickettsiae and severe fever with thrombocytopenia syndrome virus in ticks in eastern central China. Acta Parasitol Med Entomol Sin.2016;23 2:86-90; doi: 10.3969/j.issn.1005-0507. http://www.wanfangdata.com.cn/details/detail.2016;02.004.

19. Zhouxiang C, Fei W, Bangqun Q, Enfu C, Jiabing W. Investigation and disposal on the first cluster outbreak of person to person transmission of severe fever with thrombocytopenia syndrome in southern Anhui Province. Chin J Dis Control Prev.2014;18 11:1055-8.

20. Liu H, Li Q, Zhang X, Li Z, Wang Z, Song M, et al. Characterization of rickettsiae in ticks in northeastern China . Parasite Vector.2016;9 1.

21. Jing-jie W, Zhi-xin L, xiu-li W, Jing Y, Jian L, Hua-bing T, et al. Research progress of severe fever with thrombocytopenia syndrome and its etiology. Tian Jin Med J.2019;47 02:220-4.

22. Liu Y, Huang XY, Du YH, Wang HF, Xu BL. [Survey on ticks and detection of new bunyavirus in some vect in the endemic areas of fever, thrombocytopenia and leukopenia syndrome (FTLS) in Henan province]. Zhonghua Yu Fang Yi Xue Za Zhi.2012;46 6:500-4.

23. Jiang XL, Wang XJ, Li JD, Ding SJ, Zhang QF, Qu J, et al. [Isolation, identification and characterization of SFTS bunyavirus from ticks collected on the surface of domestic animals]. Bing Du Xue Bao.2012;28 3:252-7.

24. Yun SM, Song BG, Choi W, Roh JY, Lee YJ, Park WI, et al. First Isolation of Severe Fever with Thrombocytopenia Syndrome Virus from Haemaphysalis Iongicornis Ticks Collected in Severe Fever with Thrombocytopenia Syndrome Outbreak Areas in the Republic of Korea.Vector Borne Zoonotic Dis.2016;16 1:66-70; doi: 10.1089/vbz.2015.1832.

25. Yun Y, Heo ST, Kim G, Hewson R, Kim H, Park D, et al. Phylogenetic Analysis of Severe Fever with Thrombocytopenia Syndrome Virus in South Korea and Migratory Bird Routes Between China, South Korea, and Japan. Am J Trop Med Hyg.2015;93 3:468-74; doi: 10.4269/ajtmh.15-0047.

26. Kawazu S, Sugimoto C, Kamio T, Fujisaki K. Antigenic differences between Japanese Theileria sergenti and other benign Theileria species of cattle from Australia ( T. buffeli ) and Britain ( T. orientalis ). Parasitol Res.1992;78 2.

27. Bai Q, Liu Y, Yin H, Qizu Z, Dekao L, Jiaxin R, et al. Theileria Sinensis sp nov:A New Species of Bovine Theileria -Classical Taxonomic Studies. Chin J Anim Vet Sci.2002;01:73-7.

\section{Figures}



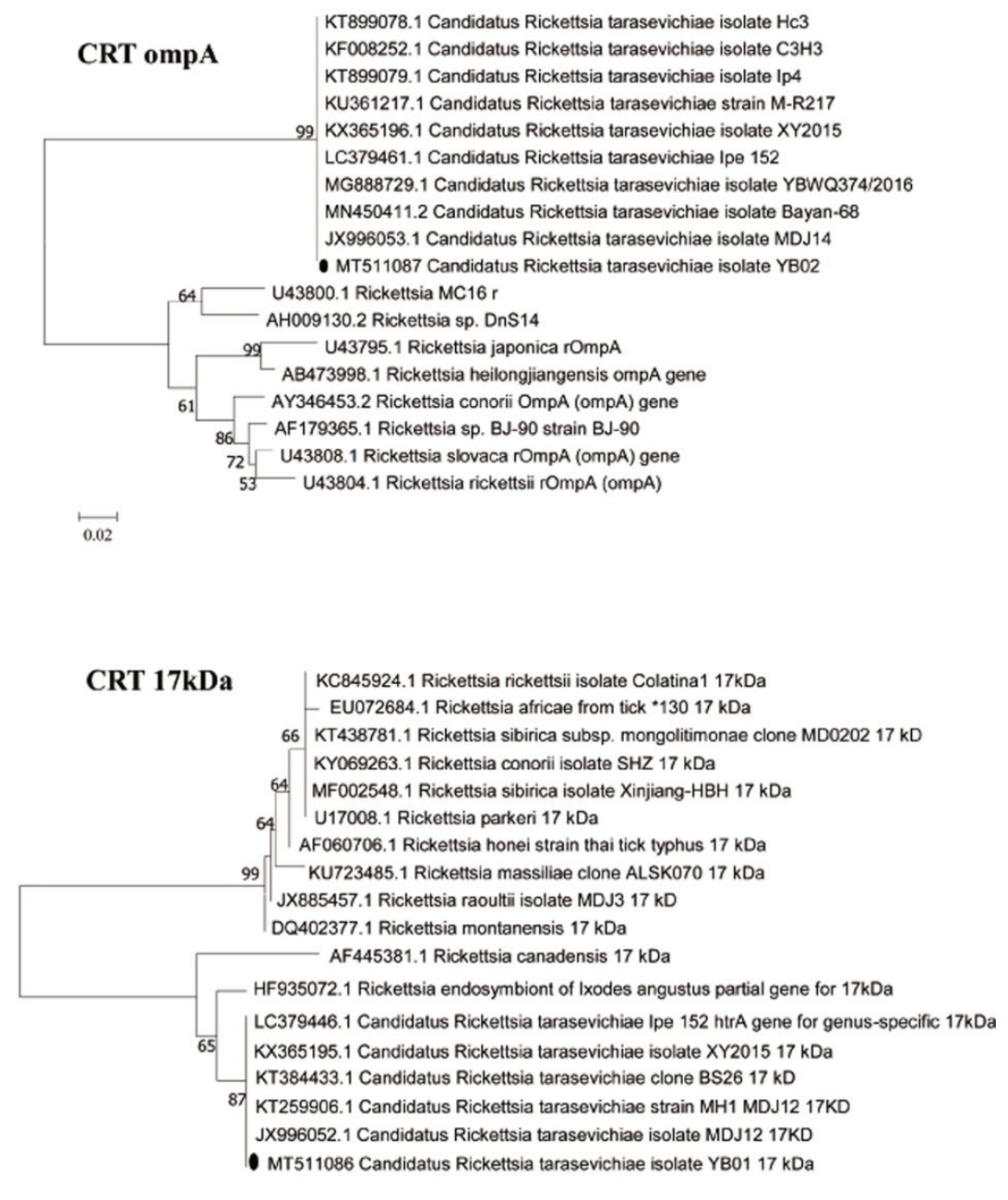

$\overrightarrow{0.02}$

Figure 1

Phylogenetic trees based on the ompA and 17kDa sequencesof CRT in this study and the GenBank database. The numbers at the nodes represent percentage of occurrence of clades in 1000 bootstrap replications of data. The gene sequences from this study are indicated by a circular in shape. 


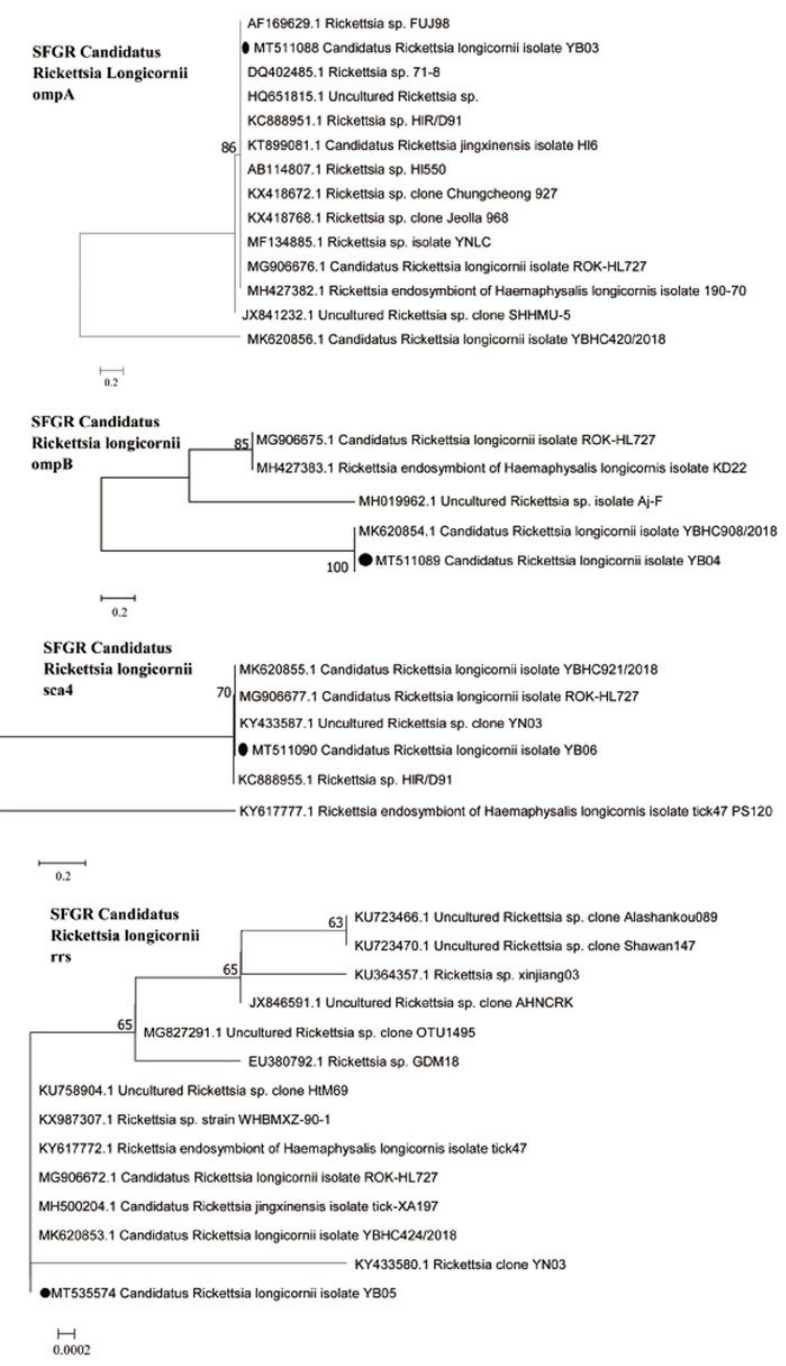

\section{Figure 2}

Phylogenetic trees based on the SFGR Candidatus Rickettsia longicornii ompA, ompB, sca4 and rrs partial sequences obtained from Haemaphysalis longicornis in this study and the GenBank database. The numbers at the nodes represent percentage of occurrence of clades in 1000 bootstrap replications of data. The gene sequences from this study are indicated by a circular in shape. 

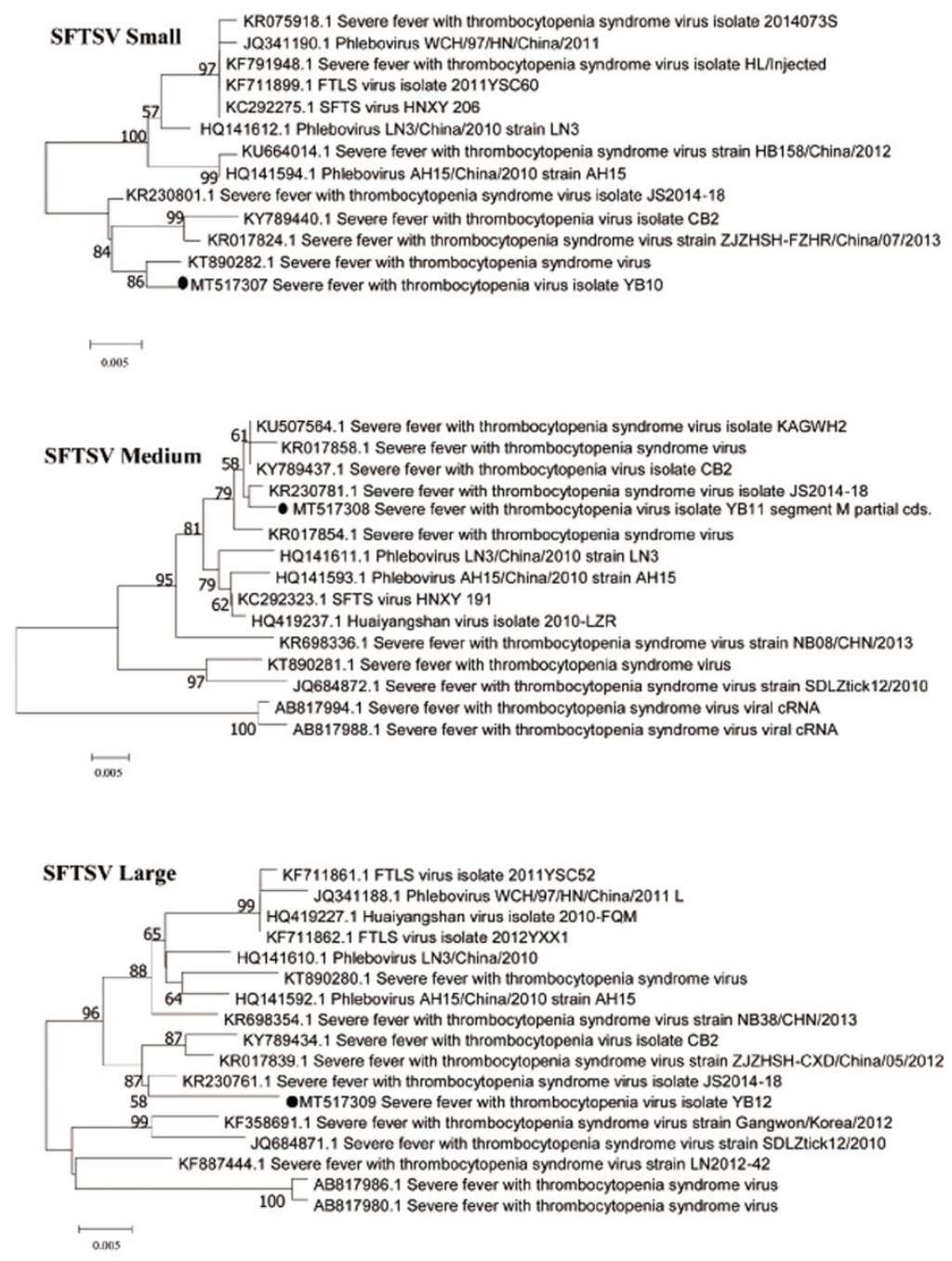

Figure 3

3Phylogenetic trees based on the SFTSV small, medium and large partial sequences obtained from Haemaphysalis longicornis in this study and the GenBank database. The numbers at the nodes represent percentage of occurrence of clades in 1000 bootstrap replications of data. The gene sequences from this study are indicated by a circular in shape.

\section{MPSP}

G7 180198.1 Theileria sergenti isolate TserGLIS piroplasm surface antigen gene
HQ322619.1 Theileria orientalis isolate Ts-U-5 major
MG784422.1 Theileria sinensis isolate GNhq8
MT068531.1 Theileria orientalis isolate CT-TO-MPSP-244
KX375400.1 Theileria sinensis isolate Jilin


Figure 4

Phylogenetic trees based on the T. orientalis MPSP sequences obtained from Haemaphysalis longicornis in this study and the GenBank database. The numbers at the nodes represent percentage of occurrence of clades in 1000 bootstrap replications of data. The gene sequence from this study is indicated by a circular in shape.

\section{Supplementary Files}

This is a list of supplementary files associated with this preprint. Click to download.

- GraphicalAbstract.eps 